\title{
Stakeholder Salience for Small Businesses : A Social Proximity Perspective
}

\section{Lähdesmäki, Merja}

2019-08

Lähdesmäki , M , Siltaoja , M \& Spence , L 2019 , ' Stakeholder Salience for Small

Businesses : A Social Proximity Perspective ' , Journal of Business Ethics , vol. 158 , no. 2 , pp. 373-385 . https://doi.org/10.1007/s10551-017-3707-z

http://hdl.handle.net/10138/308733

https://doi.org/10.1007/s10551-017-3707-z

unspecified

acceptedVersion

Downloaded from Helda, University of Helsinki institutional repository.

This is an electronic reprint of the original article.

This reprint may differ from the original in pagination and typographic detail.

Please cite the original version. 
This manuscript has been accepted for publication in Journal of Business Ethics, 2019, 158(2), 373-385.

Merja Lähdesmäki, University of Helsinki, Ruralia Institute

Marjo Siltaoja, Jyväskylä University, School of Business and Economics

Laura Spence, Royal Holloway, University of London, School of Management

\title{
STAKEHOLDER SALIENCE FOR SMALL BUSINESSES: A SOCIAL PROXIMITY PERSPECTIVE
}

\begin{abstract}
In this paper, we seek to advance stakeholder salience theory from the viewpoint of small businesses. We argue that the stakeholder salience process for small businesses is influenced by their local embeddedness and characterised by multiple relationships that the ownermanager and stakeholders share beyond the business context. This local embeddedness can be captured by the idea of social proximity. We aver that the ethics of care is a valuable ethical lens through which to understand social proximity in small businesses. We contribute to stakeholder salience theory by conceptualizing how the perceived social proximity between local stakeholders and small business owner-managers influences managerial considerations of the legitimacy, power and urgency of stakeholders and their claims. Specifically, we show the paradoxical nature of close relationships in the salience process.
\end{abstract}


Keywords: ethics of care, local embeddedness, small business, social proximity, stakeholder relations, stakeholder salience

\section{Introduction}

In a small local business, without exception, an employee becomes a close friend of yours-you know his wife (sic), since she is a part of the same community, and your children are also friends, since they go to the same school.

The small business owner-manager quoted here encapsulates the embedded nature of many small businesses. Whereas in large, multisite firms, ownership is usually geographically dispersed and top management is rotated through the firm's various locations, small business owners are more likely to live in the region and community where they conduct business (Besser and Jarnagin, 2010). Long-term residence in a town or city is associated with knowing a large number of other residents, interacting with them in multiple venues, and knowing more residents beyond the level of acquaintance (ibid). As a result, stakeholder relationships often develop into a mix of intrinsic and extrinsic friendships characterised by reciprocity, the sharing of information, non-substitutability, empathy, goodwill, liking and pleasure (Spence, 2004). It has been argued that the success of a small business is particularly related to the degree of legitimacy and approval from local stakeholders, with whom small business owner-managers often have close and personal relationships (e.g., Besser and Miller, 2001, 2013; Courrent and Gundolf, 2009). Due to such embeddedness, the dynamics of small business stakeholder relationships and ethical issues related in these relationships can differ greatly from those of large firms (e.g., Lähdesmäki and Suutari, 2012; Spence, 2016). Still, the same theories are commonly used to conceptualize stakeholder relationships 
in small and large businesses without acknowledging their contextual features (Jenkins, 2004; Laplume et al., 2008).

A popular theory used to examine the role of relationships between a business and its stakeholders is stakeholder salience theory, which determines the existence and relative importance of stakeholders and their claims from a managerial perspective (Mitchell et al., 1997). Conceptual studies have elaborated how the salience of stakeholders varies according to managerial characteristics and a firm's culture, tasks and processes (e.g., Neville et al., 2011; Rowley and Moldoveanu, 2003). Empirical studies have noted which stakeholders really matter in managerial decision-making (e.g., Agle et al., 1999; Magness, 2008; Mosakowski and Earley, 2000; Parent and Deephouse, 2007). However, the concept of stakeholder salience has not fully acknowledged how the embeddedness of a business influences the salience process of managers (e.g., Cennamo et al., 2012; Jenkins, 2004; Laplume et al., 2008; Mitchell et al., 2011; Tashman and Raelin, 2013). Accordingly, we argue that the stakeholder salience process in small businesses is influenced by their local embeddedness and characterised by multiple relationships that the owner-manager and stakeholders share beyond the business context. This local embeddedness is captured by the term 'social proximity', which refers to owner-managers' affective involvement with stakeholders based on familiarity, emotional closeness and sense of personal obligation (Huber, 2012). Although the role of social proximity has been recognised in the small business ethics and social responsibility literature (Courrent and Gundolf, 2009: Lähdesmäki and Suutari, 2012; Sen and Cowley, 2013; Spence, 2016), it has not previously been conceptualised as part of stakeholder salience.

Our study is guided by the following question: 'How does social proximity influence the stakeholder salience in locally embedded small businesses?' We seek to elaborate the stakeholder salience model in the context of small, locally embedded businesses 
through the idea of social proximity. We aver that the ethics of care is a valuable ethical lens through which to understand social proximity in small businesses. We contribute to stakeholder salience theory by conceptualizing how the perceived social proximity between local stakeholders and small business owner-managers influences managerial considerations of the legitimacy, power and urgency of stakeholders and their claims. In particular, we show the paradoxical nature of close relationships in the salience process. Accordingly, social proximity facilitates stakeholder identification and collaboration but simultaneously may complicate owner-managers' sense of moral obligation to stakeholders.

This paper is structured as follows. First, we offer a theoretical discussion of stakeholder salience and highlight the need for more size-aware research by describing the characteristics of stakeholder relations in small businesses. We proceed to examine the concept of social proximity and its dynamics in business relationships. We then advance an understanding of ethics in stakeholder salience by discussing the ethical implications of social proximity in stakeholder salience. Subsequently, we discuss how stakeholder salience among small businesses is a relational phenomenon affected by the idea of social proximity. In the final section, we discuss the contributions of the study.

\section{Stakeholder salience in small businesses}

\subsection{Stakeholder salience theory}

A cornerstone of the stakeholder salience discussion comes from Mitchell et al. (1997: 854), who defined stakeholder salience as 'the degree to which managers give priority to competing stakeholder claims'. They sought to elaborate what managers consider when weighing stakeholder concerns. A typology developed for this purpose included three principal determinants of salience: power, legitimacy and urgency. Based on these three attributes, the main propositions that arise from the typology are as follows. 
The framework suggests that the more powerful the stakeholders are, the more salient their clams are in the eyes of management. Stakeholder power is further defined as 'the ability of those who possess power to bring about the outcomes they desire' (Salancik and Pfeffer, 1974: 3). The bases of power are seen to be mainly in the type of resource used to exercise power. According to Etzioni (1964), coercive power is based on the physical resources of force, violence or restraint; utilitarian power is based on material or financial resources; and normative power is based on symbolic resources. The stakeholder salience model further proposes that the more legitimate the stakeholders and their claims are, the more likely they are to receive positive responses from a business. Legitimacy is defined as ' $a$ generalized perception or assumption that the actions of an entity are desirable, proper or appropriate within some socially constructed system of norms, values, beliefs and definitions' (Suchman, 1995: 574). Stakeholder legitimacy arises from a contract, exchange, legal title, legal right, moral right, at-risk status or moral interest in the harms and benefits generated by company actions (Agle et al. 1999). Finally, urgency is seen as the third attribute that increases the salience of the stakeholder. Stakeholder urgency can be defined as a stakeholder's claim for immediate attention based on the ideas of time sensitivity and criticality or importance (Mitchell et al., 1997). Time sensitivity refers to the degree to which a managerial delay in attending to the claim or relationship is unacceptable to the stakeholder. Criticality then refers to the importance of the claim or importance of the stakeholder.

According to the model, one stakeholder might possess all three attributes, whereas another stakeholder might possess only one or two, which affects their importance to managers and their potential influence (whether positive or negative) on the business. Mitchell et al. (1997) suggest that the combination of the three attributes yields different stakeholder classes. The first are latent stakeholders. These are low salience classes and possess only one of the attributes of power, legitimacy, and urgency - causing managers to 
pay little attention to these stakeholders. The second are expectant stakeholders, who are moderate salient classes possessing two of the attributes. The third group is definitive stakeholders, who are highly salient. Mitchell et al. (1997) further anticipated that stakeholder attributes are perceived to be impermanent and may change based on the situation and time, emphasizing the dynamic nature of the model. These assumptions were later empirically confirmed (e.g., Magness, 2008; Mosakowski and Earley, 2000).

However, the interpretation of legitimacy and power attributes in particular has yielded critical voices that claim that the treatment of these attributes oversimplifies the relationship between them. Phillips (2003), for example, argues that it is problematic to refer to powerful stakeholders who have no legitimate relationship with a business; he argues that stakeholder salience becomes more precise through the distinction between normative (moral) and derivative legitimacy. Normative stakeholders are those for whom a business has a sense of moral obligation, whereas derivative stakeholders are those whose actions managers must take into consideration due to their potential effect on the business and its normative stakeholders (Phillips, 2003: 30-31). Thus, whereas a business does not have a moral obligation to derivative stakeholders, they may possess the power to influence the wellbeing of normative stakeholders. For this reason, the claims of such stakeholders may warrant legitimate managerial attention (ibid.). Consequently, the way stakeholders become perceived as powerful or legitimate is a complex process.

We contend that despite the achievement and widespread utilization of stakeholder salience model, we need to develop a deeper understanding of the process through which managers consider stakeholder attributes in the small business context. Although stakeholder salience theory acknowledges that each attribute is a matter of multiple perceptions and socially constructed rather than objective (Mitchell et al., 1997: 868), the attributes are often nevertheless treated as if they were rationally determined by the manager. 
As a result, the theory has been critiqued for reducing stakeholder management to more or less generic skills that are or can be applied similarly regardless of the type of the business or context (e.g., Banerjee, 2008; Rowley and Moldoveanu, 2003). Indeed, decontextualisation is a particularly common problem recognised by small business researchers, according to whom standard stakeholder theorisation rarely acknowledges the specific characteristics, relationships and attributes of small businesses (e.g., Spence, 2016; Lähdesmäki and Suutari, 2012; Jenkins 2004, 2006).

\subsection{Stakeholder relations in small businesses}

A 'small business' is defined here as a business with fewer than 50 employees and with a maximum annual turnover of 10 million euros (European Commission). In addition to quantitative measures, our definition of a small business utilises qualitative characteristics to capture the meanings, beliefs and behavioural aspects that distinguish "small" businesses from their larger counterparts. One of the most often used qualitative characteristics of small businesses is the independence of the owner-manager, reflecting the close relationship between capital and management. The person responsible for managing the business is also the sole owner or one of the owners of the business (e.g., Baumback 1988; Filion 1990). This idea of businesses being independently owned and managed was also adopted as a starting point of the definition of a small business in this study. Small businesses also have qualities such as having a small market share, not being dominant in their field and being largely local in their operations (e.g., Baumback 1988; Curran and Blackburn 1994; Filion 1990).

The qualitative characteristics of small businesses are reflected in their ethics and stakeholder approach. Governance and reporting in small businesses are achieved via informal structures, emphasising word-of-mouth communication rather than formalised written reports. This supports an implicit approach to ethics and social responsibility that lacks the language and codification of ethics present in larger firms (Nielsen and Thomsen, 
2009). Small firms also tend to be flat, informally organised, and led by the owner-manager but with considerable opportunity for employee involvement. This leads to ample opportunities for the easy implementation of socially responsible practices and communication of ethical expectations (Baumann-Pauly et al., 2013). In addition, transactions in small firms tend not to be highly contractual and formalised through legalistic frameworks; rather, they are informal, reflecting the local and embedded nature of many small firms, with an emphasis on community, networks, social capital and relationships (Besser and Miller, 2001; 2013). For example, Jenkins (2006: 243) has stated that stakeholder relationships in small businesses are often based on a more informal, trusting basis and characterised by intuitive and personal engagement with less of a gap between the relative power and influence of the company and stakeholder, whereas large companies are far more likely to engage in carefully planned, formal strategic stakeholder management with the power to dictate outcomes. Similarly, whereas large businesses are most often concerned with explicitly powerful stakeholders (Parent and Deephouse, 2007), small businesses tend to be highly focused on their proximate stakeholders (e.g., Jenkins 2004; Lepoutre and Heene, 2006).

The importance of proximity was highlighted in the development of stakeholder salience theory by Driscoll and Starik (2004), who attempted to integrate the idea of proximity into the stakeholder salience discussion by supplementing power, legitimacy and urgency with geographical proximity. They argued that proximate stakeholders are those related to the organisation spatially, such as members of the same network or value chain, local customers and communities and the nearby natural environment. They concluded that geographical proximity could therefore play a role in stakeholder salience. We agree that geographical proximity is of importance in stakeholder salience for locally embedded businesses, because it produces localities through their social relationships over space (see 
also Cox, 1998). However, we argue that what matters more in terms of relationships is social proximity $^{i}$ a sense of kinship and friendship among community members. Because a few recent studies have suggested that in small businesses, the degree of social nearness or distance influences the salience of stakeholders and their claim (e.g., Siltaoja and Lähdesmäki, 2015; Spence, 2016), we next discuss a more nuanced idea of proximity and explore why it matters for small locally embedded businesses.

\subsection{Social proximity: a missing element in stakeholder salience}

Rather than an isolated entity, businesses are "constituted by or operate under influences originating from various social spheres" (Oinas, 1998: 39). This interconnectedness is often described using the concept of embeddedness, which, according to Granovetter (1992: 33), refers to the fact that "economic action is affected by actor's dyadic relationships and by the structure of the overall network of relations". The economic sphere cannot be considered as separate from other social spheres that provide supplementary motives and enacts alternative realities (Johannisson and Mönsted, 1997).

Proximity originates from the literature on embeddedness (Granovetter, 1985) and refers to the perception of social, cultural, psychological or physical closeness between a business and its stakeholders (see Boschma, 2005). While many treatments of embeddedness refer to the structure of relations that tie economic actors together (Johannisson et al., 2002), we adhere to the idea of embeddedness as relational, which refers to the kind of personal relationships people develop with each other over time (Granovetter, 1985) as promoting closer social proximity. Social proximity is defined in terms of socially embedded relations between agents on the micro level (Boschma, 2005), thus giving a theoretical means to operationalise the ideas of embeddedness. We further find that social proximity captures the detrimental aspects of close relationships, as strong ties are not always an advantage. 
Boschma and Frenken (2010) proposed the idea of a proximity paradox: bonding ties built on kinship and trust may provide protection against opportunism, but they can simultaneously facilitate unethical structures (see also Boschma, 2005). Accordingly, too much or too little social proximity may lead to an underestimation of opportunism (Uzzi, 1997) or ignorance social norms and set restrictions to individual freedom (Portes, 1998).

Literature on social proximity has been rather vague in its conceptual definitions, lacking clear explanations as to what social proximity is and how it develops. We find that a prominent conceptual connection can be developed from a social network perspective, social identity theory and group identification (see Tajfel and Turner, 1985; Rao et al., 2000). Accordingly, social proximity is defined as belonging to and similarity in a social network (e.g., Oerlemans and Meeus, 2005). We perceive a social network as a group of individuals linked to one another with different types of bonds to satisfy their goals under multiple, possibly conflicting, constraints (e.g., Kossinets and Watts, 2006). In social networks, individuals often interact with others who are similar to themselves, sharing similar backgrounds, interests and/or affiliations, i.e., those who are proximate (Sorenson, 2003).

Previous studies have demonstrated a link between social identification and feelings of proximity through three mechanisms: by creating a basis for common ground, by reducing uncertainty, and by engendering positive attributions (e.g., Wilson et al., 2008). Social identification can be defined as a process through which we reproduce ourselves in terms and categories that we share with other people (Deaux, 1994; Tajfel and Turner, 1985). This identification may become a part of individual's self-conception, which derives from his knowledge of his membership in a social group (or groups) (Tajfel 1978) - thus creating a sense of in-group membership.

To share a social identity with others does not necessarily mean that we know or interact with every other member of the designated category. It does mean, however, that 
we believe that we share numerous features with other members of the category and that, to some degree, events that are relevant to the group as a whole also have significance for the individual member (Deaux, 1994: 2). As Hinds and Mortensen (2005: 293) note, a shared identity can create a tie between distant team members that helps bridge the physical and contextual distance that otherwise separates them. Accordingly, we perceive social identification in a certain group as an essential antecedent for the existence of social proximity, as the feeling of social closeness arises from the similarity of a group.

Our conceptualisation of social proximity elaborates on the work of Huber (2012), who measured social proximity as a sense of affective relationships that arise from group identification and entail familiarity with one another (the degree to which parties know one another in their personal lives), emotional closeness (how much the parties care about one another's well-being) and a sense of personal obligation (measured by the sense of obligation to offer help that may demand a significant amount of time). In the context of locally embedded small businesses, identification with local actors involves the feeling, belief and expectation that the owner-manager fits in the group and has a place there, as well as a feeling of acceptance by the community (see McMillan and Chavis, 1986). To be a part of the local community implies a sense of shared experiences and mutuality with those also belonging to the same locality, increasing familiarity among members. However, mere awareness of group membership does not contribute to a sense of social proximity. For example, being an employee in a firm contributes to the acknowledgement of group membership but does not necessarily result in a sense of social proximity to peers and colleagues if it lacks an emotional attachment to the group members (see Karasawa, 1991). This affective aspect in social identification refers to the feeling of connection with others in the sense that 'I feel strong ties to other (in-group members)' (Cameron, 1999). Lastly, one of the features of embedded relations is the development of social bonds (Nahapiet and Ghoshal, 
1998). These social bonds contribute to shared identification but also increase the likelihood of a sense of personal obligation. For example, despite economic disadvantages, small business owner-managers may feel obligated to continue the employment of their workforce with whom they share a social bond.

We next advance our understanding of social proximity in stakeholder salience through the idea of ethic of care.

\section{Ethical implications of social proximity in stakeholder salience}

As argued by researchers since the 1990s, there is a tendency in business ethics research and teaching to turn to the well-trodden ground of what might be called rational, logical, and justice oriented ethical theory (often called 'masculinist'), such as utilitarianism, Kantianism, virtue theory, and social contract theory, overlooking feminist approaches, including the ethics of care (Borgerson, 2007; DeMoss and McCann, 1997; Liedtka, 1996). We concur with researchers (e.g., Høivik and Shanker, 2011; Høivik and Melé, 2009; Spence, 2016) that in the context of smaller businesses, the ethics of care is a more pertinent lens through which to explain and understand small firm stakeholder salience.

The ethics of care has its foundations in Carol Gilligan's book In a Different Voice (1982), which puts relationships at the very heart of moral development and commends non-violence towards others or the self as its highest principle. In the development of an ethics of care as a moral theory, philosopher Virginia Held's work emerged as an authoritative voice. She notes the importance of understanding individuals (such as ownermanagers and their colleagues) as relational rather than autonomous. Held (2006: 10-13) outlines the features of the ethics of care as (a) focusing on the moral importance of meeting the needs of particular others for whom we take responsibility; (b) valuing emotion rather than rejecting it, in the case of moral emotions that should be cultivated to implement reasons 
and to ascertain what morality recommends (e.g., empathy, sensitivity, responsiveness); (c) rejecting abstracted moral reasoning in favour of respecting the moral claims of others for whom we care; (d) including the private as well as the public spheres of life; and (e) presenting the conception of persons as relational, as previously stated.

In our view, the ethics of care adds to the explanation of why social proximity is a valuable addition to stakeholder salience, not least for small locally embedded firms. Studies have found that, in contrast to the lip service given to employees in large firms of the 'people are our most important asset' kind, in small firms, workers literally and crucially are of primary concern to owner-managers and the health of the business (e.g., Jamali et al., 2009). In addition to the prioritisation of the self and family that Spence (2016) outlines, employees are identified as the second-most important stakeholders in small business ethics and social responsibility research. We believe that this arises from co-dependency and social proximity. With social proximity comes the opportunity for a growing relationship, embedding day-to-day economic activity in social life such that work in a small business is both a technical and a social activity (Kitching, 1994). Furthermore, Spence et al. (2001) point counter-intuitively to competitors as moral stakeholders for small firms. They construct their arguments around empirical evidence that small business owner-managers in the same locality often work together as apprentice and employer, are peers in the same local trade association and exhibit camaraderie in competing against a common adversary (i.e., large firms). According to Spence et al. (2003), small businesses, which some might assume to be enemies competing for contracts, share tools and machinery and sub-contracts with each other as mutual support and for the survival of their trade. In this instance, the ethics of care explains how social proximity bonds those who share the same challenges and experiences.

In addition, the ethics of care is an important part of the blurred boundary between working small business relationships and friendship. Whereas role conflicts in larger 
firms are often controlled by more official hierarchies and rulebooks, such as codes of conduct or an ethics policy, small businesses usually lack such formal codes. This suggests that the ethics that is to be developed is founded in reciprocity, rather than the contractarian ethics that has largely dominated the stakeholder salience literature (e.g., Donaldson and Dunfee, 1994). The stakeholders who matter the most for a small business are as a result bound to have a higher moral claim. The prevailing partiality means that a compelling moral claim may be valid even when it conflicts with the requirement by moral theories that judgements are universal (Spence, 2014). For example, if stakeholders perceive that the manager is seeking to benefit from the friendship for instrumental (business) reasons, this is likely to lead to situations where the positive effects of friendships are undermined (Grayson, 2007). Thus, because social proximity enforces the possibility of role conflicts, ethics of care in relationships can help to reduce conflicts in such situations because it places an emphasis on reciprocal well-being in the context of situational sensitivity. Accordingly, it might sometimes seem that small businesses make decisions that are against the business interests, but this could be due to the fact that the organization is run in a way that is sensitive to human needs, those of both the owner-manager and stakeholders.

Building on these observations, it is important to acknowledge the lack of distinction between the public and private spheres for small firms. In this context, we might best understand this as the inclusion of the personal in professional life. The notion of leaving family and personal life 'at the door' is not one that fits well with small businesses, where managers and employees are likely to be very familiar with each other's personal circumstances and even related to each other. Similarly, discussions about work outside of the work environment are highly likely to occur, e.g., talking about a new contract at a family birthday party or school sports day. The nature and characteristics of 'family' firms are manifold, including complex governance issues with business families, sometimes with 
multiple firms, as well as with single and multi-family businesses (Steier et al., 2015). We might say that all businesses contain personal relationships and aspects of personal life, but in family firms, which accounts for most small businesses, marriage, divorce, siblings, parents and children are necessarily implicated in business life and vice versa. Even investors are quite likely to be family members. Whereas there may be efforts to disassociate the personal and the professional in large firms through laws, rules of governance and the sheer size of the bureaucracy involved, in smaller organisations, there is very little opportunity to separate the private and the public spheres, leading to both the strengths of family bonds and some difficulties that are as much at the personal level as they are at that of the business.

\section{A conceptual model for stakeholder salience in small businesses}

In this section, we conceptualise how social proximity plays a central role in the stakeholder salience of small businesses. We first introduce the concept of multiplexity, which is argued to hold an essential role in enhancing social relationships (Boissevain, 1974), particularly in the small business context (Spence and Rutherford, 2003). We then conceptualise how the perceived social proximity between small businesses and stakeholders influences managerial considerations of the legitimacy, power and urgency of stakeholders and their claims. Figure 1 illustrates this.

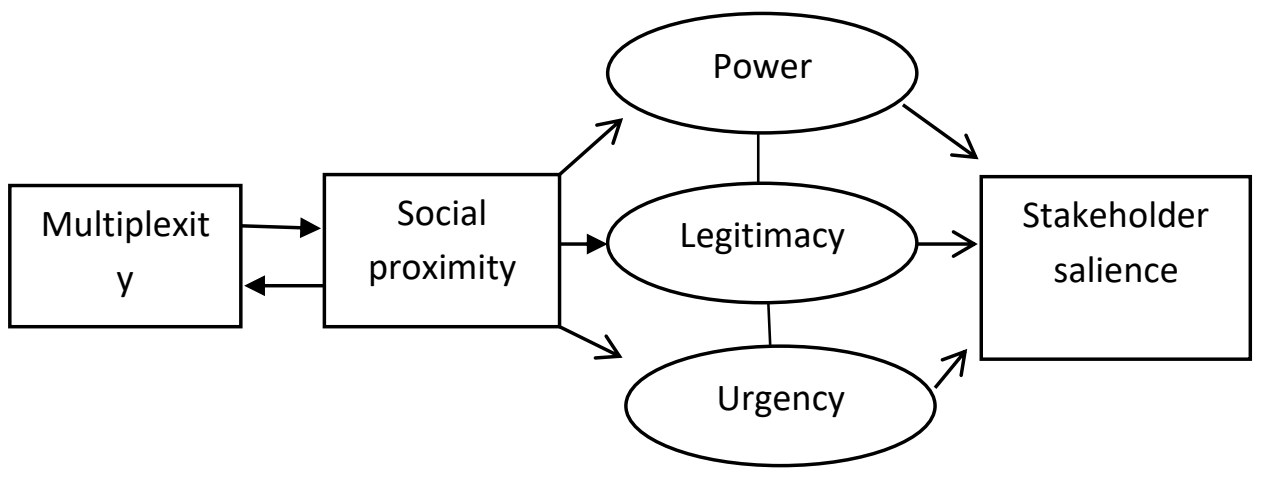


Figure 1: Managerial perspective on stakeholder salience in locally embedded small businesses

In small businesses, individual and organisational relationships frequently merge and become mutually reinforcing (Worthington et al., 2006). Business partners are typically linked to each other by additional relationships beyond the business context (e.g., Longenecker et al., 2006; Besser and Jarnagin, 2010). This kind of overlap in relationships is captured by the concept of 'multiplexity', which refers to the degree to which two actors are linked by more than one type of relationship (e.g., Brass et al., 1998; Valcour, 2002). The previous research has demonstrated that geographical proximity encourages multiplex relationships by creating opportunities for face-to-face contact (Verbrugge, 1979). Accordingly, for small locally embedded businesses, the same individuals may be simultaneously kin, neighbours and coworkers, intensifying the capacity for mutual monitoring of their ties. Multiplexity is present when the social and personal relationships and networks in which owner-managers are entwined cannot be separated from each other (Spence and Rutherfoord, 2003).

Overlapping personal and business relationships and the informality characterising these relationships are often regarded as a relative advantage for small businesses. Multiplexity is considered to enable and enhance trust in business operations (e.g., Worthington et al., 2006) and can provide a business with an important means of addressing additional resources, which can be critical to the success of many small firms (e.g., Murillo and Lozano, 2006). Similarly, multiplexity is considered as having a positive effect on business operations by increasing the social costs of unethical decision-making (Longenecker et al., 2006). Nevertheless, we suggest that multiplexity also has a negative side. Mixing business and personal relationships can also complicate business decisionmaking, because the involvement of a family member or a personal friend in the business may lead to potential conflicts of interests and ethical challenges (Cennamo et al., 2012). 
Because of the multiplexity of relationships, small business owner-managers may find it challenging to justify decisions for business-related reasons only, facing role conflicts (Siltaoja and Lähdesmäki, 2015). It can even be argued that multiplexity in business relations may appear as an exhibition of less rational business behaviour when compared to those businesses with clearer boundaries regarding business and social roles (Dyer and Handler, 1994).

Multiplexity in the small business context is further enforced by the fact that ownership and control are not usually separated into distinct functions but rather combined in the same person (e.g., Jenkins, 2006; Quinn, 1997). The combination of the roles of ownership and management can diminish the potential agency conflicts often inherent for large, publicly listed corporations. Due to the alignment of ownership and management, the role of non-economic issues, such as emotions and values, is likely to prevail when addressing stakeholder interaction (c.f. Cennamo et al., 2012). Indeed, multiplexity in social relationships expands both the emotional and instrumental exchange between two people (Verbrugge, 1979). Accordingly, we formulate the following proposition:

Proposition 1. Multiplexity is positively related to social proximity between a locally embedded business and its stakeholders.

\section{Legitimacy}

Socially proximate relationships are frequently characterized by value resemblance stemming from similar backgrounds, interests and/or affiliations (e.g. Sorenson, 2003). Because of the similarities, people expect others to be more likely to accept them, to be trustworthy and to hold beliefs that affirm their own, thereby mitigating the potential conflicts, misunderstandings, and monitoring costs that come with making connections (Rivera et al., 2010). Accordingly, social proximity is reflected in the stakeholder salience process by the 
basic idea of social interactions being more plausible between two actors that are similar in their values and attitudes (e.g. Kossinets and Watts, 2009). People not only prioritise values with which they feel comfortable but also people with whose values they feel comfortable (e.g., Schwartz, 1999; Sorenson, 2003).

In small businesses, owner-manager are often both the drivers and implementers of values (Jenkins, 2006). They are usually able to bring their own personal values to bear on business decisions (e.g., Lepoutre and Heene, 2006; Spence, 2016), because they are not as mediated and constrained by the same systems and established norms as managers in large businesses often are (Quinn, 1997). At the nexus of values, behaviours and social relations, where stakeholder salience is defined to be the degree to which managers prioritise competing stakeholders, it appears reasonable to suggest that small business ownermanagers' own values will influence the way they view stakeholder salience (c.f. Mitchell et al., 2011).

The social bonds based on similar values create moral obligations for small business owner-managers to act for the advantage of stakeholders (e.g., Scheffler, 1997). Because stakeholders are people with names and faces, most people feel a stronger obligation to help those in social proximity (Frederiksen, 2010). For example, if the small business owner-manager is a member of a group where certain values play a significant role (e.g., a religious group, political party or NGO), the members of the group are likely to share a high sense of social proximity. It can be problematic to ignore the calls from such a group, even if the decision is more beneficial personally than in terms of the business. The kinship relations and perceived resemblance in values between owner-managers and stakeholders result in increased moral value of proximate relationships. Thus, social proximity may be a relative strength in decision making but can simultaneously cause complexities if social proximity is used as a determinant to evaluate who is a legitimate stakeholder and whose claim should be 
prioritized. More specifically, proximate stakeholders may not necessarily be legitimate in a normative sense, but socially proximate relations may dispel this. In relation to previous theorisations on stakeholder salience, we propose the following:

Proposition 2a: Social proximity increases the legitimacy of those stakeholders and their claims who are perceived to hold similar values with the owner-manager

Thus, what follows from this proposition is that if the owner-manager does not perceive closeness to the values of stakeholders who in theory hold a legitimate stakeholder role, their claims can be more easily ignored due to the proximity paradox. For example, Lähdesmäki and Suutari (2012) found that the social distance between a small business and stakeholders can lead to owner-managers' lack of corporate responsibility towards stakeholders with whom managers do not identify. This reflects the incorporation of partiality in the ethics-ofcare perspective, where it is clear that an actor will give preference to those with whom they have a closer relationship, which might also be reflected in similar values. Accordingly, we propose the following:

Proposition 2b: Low social proximity decreases the legitimacy of those stakeholders and their claims who are not perceived to hold similar values with the owner-manager

Power

Since a majority of small businesses are family owned and managed, stakeholder salience is more likely based on normative rather than utilitarian perceptions of power (Mitchell et al., 2011). Whereas utilitarian power is based on stakeholders' ability to control particularly the tangible resources on which a business depends, normative power is linked to symbolic resources. These symbolic resources usually relate to one's reputation and value as perceived by others (Fuller and Tian, 2006). 
In locally embedded small businesses, reputation as an essential symbolic resource reflecting the normative power in stakeholder relations becomes particularly emphasised since businesses tend to rely heavily on few stakeholders in their local community and their activities are often under constant public scrutiny by local stakeholders (Quayle, 2002). Therefore, local embeddedness renders small businesses very susceptible to criticism from stakeholders, and such criticism can negatively affect businesses through a loss of reputation and, accordingly, a loss of social status and exclusion from social networks (see Goss, 2005). Lähdesmäki and Siltaoja (2010), for example, suggest that in the context of small business, reputation can be understood as a powerful control mechanism reflecting small businesses' compliance with local norms. Furthermore, since in small firms, the business is personal (Kitching, 1994) and linked very much to the founder in particular (Fauchart and Gruber, 2011), firm and personal reputations are often coterminous. Accordingly, the reputation of a business represents a potential risk to the owner-manager's own status among stakeholders and vice versa.

For small businesses, the local community itself operates as a dense network; both the business and stakeholders are highly susceptible to each other's actions. The motives of stakeholder groups to express their claims are additionally conditioned by the degree of overlap across stakeholder groups (Rowley and Moldoveanu, 2003). These networks generate collective knowledge sharing (Ashmore et al., 2004) and potentially strengthen local normative sanctioning mechanisms, leading to constraints on the actions of a local business (cf. Rowley, 1997). In proximate networks that consist of owner-managers' in-group members, stakeholders are better able to constrain the focal firm because the network has an effective communication structure and often shares similar behavioural expectations towards the focal firm (Rowley, 1997). 
Reputation as a symbolic resource in socially proximate relations means that both parties are likely to seek to maintain and contribute to each other's favourable social evaluation. However, it simultaneously means that a good reputation increases stakeholders' expectations regarding the firm's future behaviour (Mishina et al., 2010). Thus, as we can understand from an ethics of care perspective, a violation in close relationships will be associated with a greater violation of expectations compared to an event of similar wrongdoing in a relationship that is socially more distant (cf. Zavyalova et al., 2015). Social proximity thus increases the significance of stakeholders' favourable evaluations, since in reputation construction, the opinions of the actors who are really perceived to know the object of evaluation matter the most. Accordingly, keeping close, high-identification stakeholders' content, owner-managers are likely to pay more direct attention to their claims. We therefore offer the following proposition:

Proposition 3a: Social proximity increases the normative power of in-group stakeholders and their claims

Thus, what follows from this proposition is that owner-managers may not sufficiently acknowledge the power of out-group stakeholders. This finding is observed because, as we know from previous research on the ethics of care and small business social responsibility (Spence, 2016), small business owner-managers tend to value personal relationships, and such networked relationship constitute a key business resource (Spence et al., 2003). Thus, they may, for example, find it complex understanding non-traditional networks such as social media as a source of normative power (cf. Durkin et al., 2013). Accordingly, we propose the following:

Proposition 3b: Low social proximity decreases the normative power of out-group stakeholders and their claims 


\section{Urgency}

Urgency is a two-element construct that includes (1) time sensitivity, meaning the degree to which management's delay in attending to the claim or relationship is unacceptable to the stakeholder, and (2) urgency, referring to the importance of the claim or the relationship to the stakeholder (Mitchell et al., 1997). These elements can result in varying interpretations in firms that operate beyond mere business logic and can be quite complex regarding the type of business (Mitchell et al., 2011). We find that socially proximate stakeholder relationships can paradoxically both increase and decrease owner-managerial interpretations of the urgency of stakeholders' claims.

First, because of multiplexity, the majority of small business owner-managers' ties are based on a long-term perspective. This leads to the consideration of the urgency of claims by acknowledging past, present and future embedded relationships. This is particularly true when business relationships mix with friendships. Friendships include the expectation for an exclusively intrinsic orientation. An intrinsic relational orientation is the desire to maintain a relationship because of inherently enjoyable aspects of the relationship and because the relationship itself generates its own rewards (Rempel et al., 1985). Friends are often more loyal as business partners as well as more productive and committed to contribute to business goals (Grayson, 2007; Haytko, 2004). Thus, entirely in keeping with an ethics of care viewpoint, managers are likely to prioritise urgent claims of those stakeholders whose wellbeing matters most to them (Spence, 2016). We therefore offer the following proposition:

Proposition 4a: Social proximity increases the perceived urgency (importance) of a stakeholder claim

However, in terms of time sensitivity, social proximity may also decrease stakeholder salience. Because the friendship role may evoke a sense of stakeholder loyalty, the owner- 
manager can perceive this unconditional support to extend into business conflicts. For example, if the continuity of the owner-manager's business depends on the prioritisation of two competing urgent claims (e.g., taking care of loan payments versus paying a supplier), managers may seek compassion from their close stakeholders and rely on care-based stakeholders' prosociality, i.e., behaviour that benefits another person, often at the instigation of the benefactor (Simpson and Willer, 2008: 39). Whereas exchange partners in a business often gain important advantages by maintaining information asymmetries (Desiraju and Moorthy, 1997), friendship relations are associated with intimate self-disclosure (Held, 2006), and friends are expected to share personal problems with and to 'open up' their lives more fully to each other (Haytko, 2004). Accordingly, a manager may reveal the financial hardship to a friend-stakeholder with an interest (e.g., in hopes of decreasing the urgency of the claim) to maintain the business's existence and the owner's personal well-being. Because social proximity also increases both stakeholder power and legitimacy, we offer the following propositions from the managerial viewpoint:

Proposition 4b: In the case of two or more competing claims from powerful stakeholders, social proximity decreases the urgency (time sensitivity) of stakeholder claims.

\section{Discussion and conclusions}

Since the earliest landmark studies in stakeholder salience literature, there has been little theoretical development in terms of how stakeholder salience theory applies to various types of firms (see, however, Mitchell et al., 2011; Cennamo et al., 2012). By synthesising the literature on small business stakeholder relations, our study demonstrates how social proximity influences stakeholder salience in locally embedded small businesses. Accordingly, we conceptualise how powerful, urgent and legitimate stakeholder claims are perceived in the context of socially embedded decision-making. We show that stakeholder 
salience for small businesses is embedded in social situations in which the feelings of social closeness between a business and a certain actor have a significant impact on whether the actor and their claims are prioritised as powerful, urgent and/or morally legitimate. As a result, we argue that social proximity influences the ways in which businesses make sense of stakeholder power, urgency and legitimacy. Our study then elaborates and conceptualises the work of Neville et al. (2011), who suggested that proximity's influence upon stakeholder salience in general is subsumed within power and legitimacy attributes.

We also extend the discussion on the role of close and emotional bonds between stakeholders and small businesses. Although they have been considered as a relative necessity for effective relationships, particularly due to their potential for generating business-stakeholder welfare (Sen and Crowley, 2013), our theorisation elaborates the complex side of embedded relations in small businesses (Siltaoja and Lähdesmäki, 2015) by conceptualising their significance for stakeholder salience. First, social proximity may prompt owner-managers of locally embedded small businesses to accede to stakeholder claims that, from a stakeholder salience theory perspective, are less legitimate or could even seem illegitimate (cf. Mitchell et al., 1997). Second, social proximity also works as a 'legitimating device' for owner-managers to favour personal relationships over business ones. Indeed, although it is often suggested that businesses (especially smaller businesses) must develop close relationships with their partners, the relationships can be too close, which can result in ethical problems (see Ayios et al., 2014; Portes, 1998; Uzzi, 1997). For example, when personal relationships take precedence over the actual qualifications of a potential workforce, business partners and societal stakeholders, the danger of nepotism prevails. It may foster feelings of inequality in the workplace and eventually result in negative consequences on firm performance and social welfare. 
Our propositions further enrich the understanding of stakeholder management as a relational phenomenon. To accomplish this, we elaborated stakeholder salience from an ethic of care perspective in which the traditional idea of autonomy is replaced with relationships and connections-often multiplex connections-between people. Many theories of business ethics emphasise the importance of neutrality, rationality, impartiality and objectivity (Held, 2006) as the most important moral qualities of a manager, which are opposite to ideas associated with the ethic of care (Tronto, 1993). However, their fit to actual stakeholder situations is poor (see Rowley and Moldoveanu, 2003). This also affects the stakeholder salience process, making it not only a managerially determined event but also a social event (see Tashman and Raelin, 2013). Indeed, whereas the dominant masculine and individualistic approach poses problems for understanding both ethics and the stakeholder firm as relational accomplishments, an ethic of care unveils the sense of moral obligations related to stakeholder salience in small businesses. This helps to present small business owner-managers as moral agents embedded in important relationships with others and as those who acquire a sense of moral identity through interactive patterns of behaviour and interpretation (Addelson, 1991).

While operating in social networks characterised by multiplexity, small businesses may be perceived as entities that socialise care (Tronto, 1993). However, such positioning as care providers can be problematic for small businesses, as they face continuously growing societal expectations, particularly in terms of corporate social responsibility. This discussion often treats small businesses in a patriarchal sense, meaning that expectations towards the corporate social responsibility of small businesses are limited to care, whereas large firms handle different and more complex issues (e.g., Perrini et al., 2007). Thus, to socialise care, the premises should emphasise authenticity and empowerment in 
small businesses activities. Otherwise, increasingly proximate relationships may also become a burden for small businesses.

Our conceptualisation of social proximity as an intrinsic element in the stakeholder salience process was done with a particular view to locally embedded small businesses. However, we consider that there are strong possibilities for our proposals to have applications beyond small firms. For example, smaller departments or subsidiaries of large firms may exhibit some of the features of small firms. Thus, our study calls for an empirical examination of various situations and contexts that either facilitate or complicate socially proximate stakeholder relations, as socially proximate relationships can result in multiple outcomes. Previous studies have focused on the positive aspects of social proximity, leading to somewhat one-sided and uncritical views that marginalise the power dynamics inherent in social proximity. Future research should therefore outline under what conditions unethical/ethical activity can happen, its driving or hindering forces and what kinds of multiple outcomes socially proximate stakeholder salience processes can generate. The prioritization of proximate stakeholders over more distant ones can have economic and social implications for a small business which research should further address. Thus, a typology of stakeholders based on social proximity, for example, could provide small business ownermanagers means to better perceive the importance of developing ties both with socially proximate and distance stakeholders. Indeed, much remains to be explored regarding how small businesses navigate stakeholder relationships.

\section{Compliance with ethical standards}

All procedures performed in studies involving human participants were in accordance with the ethical standards of the institutional and/or national research committee and with the 1964 Helsinki declaration and its later amendments or comparable ethical standards. 
Informed consent was obtained from all individual participants included in the study.

\section{Funding}

Merja Lähdesmäki and Marjo Siltaoja have received research grants from Academy of Finland (Grant Numbers 259482 and 260138). The authors declare that they have no conflict of interest.

\section{References}

Addelson, K.P. (1991). Impure thoughts: Essays on philosophy, feminism, and ethics. Philadelphia, Temple University Press.

Agle, B.R., Mitchell, R.K. \& Sonnenfeld, J.A. (1999). Who matters to CEOs. An investigation of stakeholder attributes and salience, corporate performance and CEO values. Academy of Management Journal, 42(5): 507-527.

Ashmore, R.D., Deaux. K. \& McLaughlin-Volpe, T. (2004). An organizing framework for collective identity: Articulation and significance of multidimensionality. Psychological Bulletin, 130(1): 80-114.

Ayios, A., Jeurissen, R., Manning, P. and Spence, L.J. (2014). Social Capital: A review from an ethics perspective. Business Ethics: A European Review. 23(1): 108-124.

Banerjee, S.B. (2008). Corporate social responsibility: The good, the bad and the ugly. Critical Sociology, 34(1): 51-79.

Baumann-Pauly, D., Wickert, C., Spence, L. \& Scherer, A. (2013). Organizing corporate social responsibility in small and large firms: Size matters. Journal of Business Ethics, 115(4): 693-705.

Baumback, C.M. (1988). How to organize and operate a small business. (8th ed.). Englewood Cliffs: Prentice Hall.

Besser, T.L. \& Jarnagin, S.K. (2010). Corporate social responsibility. Small businesses and 
small towns. History of corporate social responsibility project. Minneapolis, MN: Center for Ethical Business Cultures located at the Opus College of Business, University of St.Thomas - Minnesota.

Besser, T.L. \& Miller, N. (2001). Is the good corporation dead? The community social responsibility of small business operators. Journal of Socio-Economics, 30(3): 221-241.

Besser, T.L. \& Miller, N. (2013). Social capital, local businesses, and amenities in U.S. rural prairie communities. Journal of Rural Studies, 32: 186-195.

Boissevain, J. 1974. Friends of friends: Networks, manipulators, and coalitions. New York: St. Martin's Press.

Borgerson, J.L. (2007). On the harmony of feminist ethics and business ethics. Business and Society Review, 112(4): 477-509.

Boschma, R.A. (2005). Proximity and innovation: A critical assessment. Regional Studies, 39(1): 61-74.

Boschma, R. \& Frenken, K. (2010). The spatial evolution of innovation networks. A proximity perspective. In R. Boschma \& R. Martin (Eds.), The Handbook of Evolutionary Economic Geography: 120-135. Cheltenham: Edward Elgar.

Brass, D.J., Butterfield, K.D. \& Skaggs, B.C. (1998). Relationships and unethical behavior: A social network perspective. Academy of Management Review, 23(1): 14-31.

Cameron, J.E. (1999). Social identity and the pursuit of possible selves: Implications for the psychological well-being of university students. Group Dynamics: Theory, Research, and Practice, 3(3): 179-189.

Cennamo, C., Berrone, P., Cruz, C. \& Gomez-Mejia, L.R. (2012). Socioemotional wealth and proactive stakeholder engagement: Why family-controlled firms care more about their stakeholders. Entrepreneurship Theory \& Practice, 36(6): 1153-1173.

Courrent, J-M. \& Gundolf, K. (2009). Proximity and micro-enterprise manager's ethics: A 
French empirical study of responsible business attitudes. Journal of Business Ethics, 88(4): $749-762$.

Cox, K. (1998). Locality and community: Some conceptual issues. European Planning Studies 6(1): 17-30.

Curran J. \& Blackburn, R. (1994). Small firms and local economic networks. The death of the local economy? London: Paul Chapman Publishing Ltd.

Deaux, K. (1994). Social identity. In J. Worrell (Ed.), Encyclopedia of women and gender (Vol. 2). (pp. 1059-1067). San Diego, CA: Academic Press.

Desiraju, R. \& Moorthy, S. (1997). Managing a distribution channel under asymmetric information with performance requirements. Management Sci., 43(12): 1628-1644.

DeMoss, M. \& McCann, G. (1997). Without a care in the world: The business ethics course and its exclusion of a care perspective. Journal of Business Ethics, 16: 435-443.

Donaldson, t. \& Dunfee, T.W. (1994). Toward a unified conception of business ethics: Integrative social contracts theory. Academy of Management Review, 19(2): 252-284.

Driscoll, C. \& Starik, M. (2004). The Primordial stakeholder: Advancing the conceptual consideration of stakeholder status for the natural environment. Journal of Business Ethics, 49(1): 55-73.

Durkin, M., McGowan, P. \& McKeown, N. (2013). Exploring social media adoption in small to medium-sized enterprises in Ireland. Journal of Small Business and Enterprise Development, 20(4): 716-734.

Dyer, W. G., \& Handler, W. (1994). Entrepreneurship and family business: Exploring the connections. Entrepreneurship Theory and Practice, 19: 71-71.

Etzioni, A. (1964). Modern organizations. Englewood Cliffs, NJ: Prentice-Hall.

European Commission. (2003). Definition of micro, small and medium-sized enterprises. http://europa.eu/legislation_summaries/enterprise/business_environment/n26026_en.htm. 
Fauchart, E. \& Gruber, M. (2011). Darwinians, communitarians, and missionaries: The role of founder identity in Entrepreneurship. Academy of Management Journal, 54(5): 935-957.

Filion, L.J. (1990). Free trade: The need for a definition of small business. Journal of Small Business \& Entrepreneurship, 7(2): 33-46.

Frederiksen, C.S. (2010). The relation between policies concerning corporate social responsibility (CSR) and philosophical moral theories - An empirical investigation. Journal of Business Ethics, 93: 357-371.

Fuller, T. \& Tian, Y. (2006). Social and symbolic capital and responsible entrepreneurship: An empirical investigation of SME narratives. Journal of Business Ethics, 67(3): 287-304.

Gilligan, C. (1982). In a Different Voice. Cambridge, Massachusetts: Harvard University Press.

Goss, D. (2005). Shumpeter's legacy? Interaction and emotions in the sociology of entrepreneurship. Entrepreneurship Theory and Practice, 29(2): 205-218.

Granovetter, M. (1985). Economic action and social structure: The problem of embeddedness. American Journal of Sociology, 91(3): 481-510.

Granovetter, M. (1992). Problems of explanation in economic sociology. In Nohria, N. and Eccles, R. (eds), Networks and organizations: Structure, form and action. Boston: Harvard Business School Press. 25-56.

Grayson, K. (2007). Friendship versus business in marketing relationships. Journal of Marketing, 71(4): 121-139.

Haytko, D. L. (2004). Firm-to-Firm and Interpersonal Relationships: Perspectives from Advertising Agency Account Managers. Journal of the Academy of Marketing Science, 32(3): 312-28.

Held, V. (2006). The Ethics of Care: Personal, Political, and Global. Oxford University Press: Oxford, UK. 
Hinds, P. J., \& Mortensen, M. (2005). Understanding conflict in geographically distributed teams: The moderating effects of shared identity, shared context, and spontaneous communication. Organization science, 16(3): 290-307.

Høivik, H. von Weltzien, \& Melé, D. (2009). Can an SME become a global corporate citizen? Evidence from a case study. Journal of Business Ethics, 88(3): 551-563.

Høivik, H. von Weltzien, \& Shankar, D. (2011). How can SMEs in a cluster respond to global demands for corporate responsibility? Journal of Business Ethics, 101(2): 175-195.

Huber, F. (2012). On the role and interrelationship of spatial, social and cognitive proximity: Personal knowledge relationships of $R \& D$ workers in the Cambridge information technology cluster. Regional Studies, 46: 1169-1182.

Jamali, D., Zanhour, M. \& Keshishian, T. (2009). Peculiar strengths and relational attributes of SMEs in the context of CSR. Journal of Business Ethics, 87(3): 355-377.

Jenkins, H. (2004). A critique of conventional CSR theory: An SME perspective. Journal of General Management, 29(4): 37-57.

Jenkins, H. (2006). Small business champions for corporate social responsibility. Journal of Business Ethics, 67(3): 241-256.

Johannisson B. \& Mönsted M. (1997). Contextualising entrepreneurial networking - The case of Scandinavia. International Studies of Management and Organisations, 27(3): 109-136.

Johannisson, B., Ramírez-Pasillas, M., \& Karlsson, G. (2002). The institutional embeddedness of local inter-firm networks: a leverage for business creation. Entrepreneurship \& Regional Development, 14(4): 297-315.

Karasawa, M. (1991).Toward an assessment of social identity: The structure of identification and its effects on in-group evaluations. British Journal of Social Psychology, 30(4): 293307. 
Kitching, J. (1994). Employer's work- force construction policies in the small service sector enterprise, in D. Storey, and J. Atkinson, (eds) Employment, the Small Firm, and the Labour Market, London, UK: Routledge, pp. 103-46.

Kossinets, G. \& Watts, D.J. (2006). Empirical analysis of an evolving social network. Science, 311(6): 88-90.

Laplume, A., Sonpar, K. \& Litz, R. (2008). Stakeholder theory: A longitudinal review of a theory that moves us. Journal of Management, 24(6): 1152-1189.

Lepoutre, J. \& Heene, A. (2006). Investigating the impact of firm size on small business social responsibility: A critical review. Journal of Business Ethics, 67(3): 257-273.

Liedtka, J. (1996). Feminist morality and competitive reality: A role for an ethics of care. Business Ethics Quarterly, 6(2): 179-200.

Longenecker, J.G., Moore, C.W., Petty, J.W., Palich, L.E. \& McKinney, J.A. (2006). Ethical attitudes in small businesses and large corporations: Theory and empirical findings from a tracking study spanning three decades. Journal of Small Business Management, 44(2): 167-183.

Lähdesmäki, M. \& Siltaoja, M. (2010). Towards variety of meanings - Multiple representations of reputation in small business context. British Journal of Management, 21(1): 207-222.

Lähdesmäki, M. \& Suutari, T. (2012). Keeping at arm's length or searching for proximity? Corporate social responsibility as a reciprocal process between small businesses and the local community. Journal of Business Ethics, 108(4): 481-493.

Magness, V. (2008). Who are the stakeholders now? An empirical examination of the Mitchell, Agle, and Wood theory of stakeholder salience. Journal of Business Ethics, 83(2): 177-192. 
McMillan, D.W. \& Chavis, D.M. (1986). Sense of community: A definition and theory. Journal of Community Psychology, 14: 6-23.

Mishina,Y. Dykes, B.J., , Block E.S. \& Pollock, T.G. (2010). Why "good" firms do bad things: The effects of high aspirations, high expectations, and prominence on the incidence of corporate illegality. Academy of Management Journal, 53(4): 701-722.

Mitchell, R.K., Agle, B.R. \& Wood, D.J. (1997). Toward a theory of stakeholder identification and salience: Defining the principle of who and what really counts. Academy of Management Review, 22(4): 853-886.

Mitchell, R.K., Agle, B.R., Christman, J.J. \& Spence, L.J. (2011). Toward a theory of stakeholder salience in family firms. Business Ethics Quarterly, 21(2): 235-255.

Mosakowski, E., \& Earley, P.C. (2000). A selective review of time assumptions in strategy research. Academy of Management Review, 25: 796-812.

Murillo, D. \& Lozano, J.M. (2006). SMEs and CSR: An approach to CSR in their own words. Journal of Business Ethics, 67(3): 227-240.

Nahapiet, J., \& Ghoshal, S. (1998). Social capital, intellectual capital, and the organizational advantage. Academy of management review, 23(2): 242-266.

Neville, B.A., Bell, S.J. \& Whitwell, G.J. (2011). Stakeholder salience revisited: Refining, redefining, and refueling an underdeveloped conceptual tool. Journal of Business Ethics, 102(3): $357-378$.

Nielsen, A.E. \& Thomsen, C. (2009). Investigating CSR communication in SMEs: A case study among Danish middle managers. Business Ethics: A European Review, 18(1): 8393.

Oinas P. (1998). The Embedded Firm? Predule for a Revived Geography of Enterprise, Helsinki School of Economics and Business Administration, A-143, Helsinki. 
Oerlemans, L. \& Meeus, M. (2005). Do organization and spatial proximity impact firm performance? Regional Studies, 39(1): 89-104.

Parent, M. M., \& Deephouse, D. L. (2007). A case study of stakeholder identification and prioritization by managers. Journal of business ethics, 75(1): 1-23.

Perrini, F., Russo, A. \& Tencati, A. (2007). CSR strategies of SMEs and large firms. Evidence from Italy. Journal of Business Ethics, 74: 285-300.

Phillips, R. (2003). Stakeholder legitimacy. Business Ethics Quarterly, 13(1): 25-41.

Portes, A. (1998). Social Capital: Its Origins and Applications in Contemporary Sociology. Annual Review of Sociology 24: 1-24.

Quayle, M. (2002). E-commerce: The challenge for UK SMEs in the twenty-first century. International Journal of Operations and Production Management, 22(10): 1148-1161.

Quinn, J.J. (1997). Personal ethics and business ethics: The ethical attitudes of owner/managers of small business. Journal of Business Ethics, 16(2): 119-127.

Rao, H., Davis, G. F., \& Ward, A. (2000). Embeddedness, social identity and mobility: Why firms leave the NASDAQ and join the New York Stock Exchange. Administrative Science Quarterly, 45(2), 268-292.

Rempel, J. K., Holmes, J.G. \& Zanna, M.P. (1985). Trust in close relationships. Journal of Personality and Social Psychology, 49: 95-112.

Rivera, M.T., Soderstrom, S.B. \& Uzzi, B. (2010). Dynamics of dyads in social networks: Assortative, relational, and proximity mechanisms. Annual Review of Sociology, 36: 91115.

Rowley, T.J. (1997). Moving beyond dyadic ties. A network theory of stakeholder influences. Academy of Management Review, 22(4): 887-910. 
Rowley, T.J. \& Moldoveanu, M. (2003). When will stakeholder groups act? An interest- and identity-based model of stakeholder group mobilization. Academy of Management Review, 28(2): 204-219.

Salancik, G.R. \& Pfeffer, J. (1974). The bases and use of power in organizational decision making: The case of a university budget. Administrative Science Quarterly, 19: 453-473.

Scheffler, S. (1997). Relationships and responsibilities. Philosophy \& Public Affairs, 26(3): 189-209.

Schwartz, S. (1999). A theory of cultural values and some implications for work. Applied Psychology: An International Review, 48(1): 23-47.

Sen, S. \& Cowley, J. (2013). The relevance of stakeholder theory and social capital theory in the context of CSR in SMEs: An Australian perspective. Journal of Business Ethics, 118: 413-427.

Siltaoja, M. \& Lähdesmäki, M. (2015). From rationality to emotionally embedded elations: Envy as a signal of power in stakeholder relations. Journal of Business Ethics, 128(4): 837-850.

Simpson, B., \& Willer, R. (2008). Altruism and indirect reciprocity: The interaction of person and situation in prosocial behavior. Social Psychology Quarterly, 71(1), 37-52.

Sorenson, O. (2003). Social networks and industrial geography. Journal of Evolutionary Economics, 13(5): 513-527.

Spence, L.J. (2004). Forever friends? Friendship, dynamic relationships and small firm social responsibility. Brunel University, Brunel Research in Enterprise, Innovation, Sustainability and Ethics.

Spence, L. J. (2014). Business ethics and social responsibility in small firms. In E. Chell \& M. Karatas-Özkan (Eds.), Handbook of research on small business and entrepreneurship. Cheltenham, UK; Northampton, MA, USA: Edward Elgar. 
Spence, L.J. (2016). Small business social responsibility: Redrawing core CSR theory. Business \& Society. 55(1): 23-55.

Spence, L.J., Coles, A-M. \& Harris, L. (2001). The forgotten stakeholder? Ethics and social responsibility in relation to competitors. Business and Society Review, 106(4): 331-352.

Spence, L.J. \& Rutherfoord, R. (2003). Small business and empirical perspectives in business ethics: Editorial. Journal of Business Ethics, 47(1): 1-5.

Spence, L.J., Schmidpeter, R., \& Habisch, A. (2003). Assessing social capital: Small and medium sized enterprises in Germany and the UK. Journal of Business Ethics, 47(1): 1729.

Steier, L. P., Chrisman, J. J. \& Chua, J. H. (2015). Governance challenges in family businesses and Business Families. Entrepreneurship Theory and Practice. doi: 10.1111/etap.12180.

Suchman, M.C. (1995). Managing legitimacy: Strategic and institutional approaches. Academy of Management Review, 20(3): 571-610.

Tajfel, H. (1978). "Social Categorization, Social Identity and Social Comparison." In Differentiation between Social Groups: Studies in the Social Psychology of Intergroup Relations, edited by H. Taifel, 61-76. London: Academic Press.

Tajfel, H. \& Turner, J.C. (1985). The social identity theory of intergroup behavior. In S. Worchel \& W.G. Austin (Eds.) Psychology of intergroup relations (2nd edition, pp. 7-24). Chicago: Nelson-Hall.

Tashman, P. \& Raelin, J. (2013). What and what really matters to the firm: Moving stakeholder salience beyond managerial perceptions. Business Ethics Quarterly, 23(4): 591-616.

Tronto, J.C. (1993). Moral boundaries: A political argument for an ethic of care. New York: Routledge. 
Uzzi, B. (1997). Social structure and competition in interfirm networks: The paradox of embeddedness. Administrative Science Quarterly, 42(1): 35-67.

Valcour, P.M. (2002). Managerial behavior in a multiplex role system. Human Relations, 55(10): 1153-1188.

Verbrugge, L.M. (1979). Multiplexity in adult friendships. Social Forces, 57(4): 1286-1309.

Wilson, J. M., O'Leary, M., Metiu, A., \& Jett, Q. R. (2008). Perceived Proximity in Virtual Work:: Explaining the Paradox of Far-but-Close. Organization Studies, 29 (7): 979-1002.

Worthington, I., Ram, M. \& Jones, T. (2006). Exploring corporate social responsibility in the U.K. Asian small business community. Journal of Business Ethics, 67(2): 201-217.

' In this study, the concept of locality includes the idea of local community as the embodiment of a certain geographical closeness and social proximity in terms of feelings of belonging and similarity. 